University of Wollongong

Research Online

Faculty of Social Sciences - Papers (Archive) Faculty of Arts, Social Sciences \& Humanities

2014

The engagement of social media technologies by undergraduate informatics students for academic purpose in Malaysia

Jane Lim See Yin

INTI Laureate International Universities

Shirley Agostinho

University of Wollongong, shirleya@uow.edu.au

Barry Harper

University of Wollongong, bharper@uow.edu.au

Joe F. Chicharo

University of Wollongong, chicharo@uow.edu.au

Follow this and additional works at: https://ro.uow.edu.au/sspapers

Part of the Education Commons, and the Social and Behavioral Sciences Commons

Research Online is the open access institutional repository for the University of Wollongong. For further information contact the UOW Library: research-pubs@uow.edu.au 


\title{
The engagement of social media technologies by undergraduate informatics students for academic purpose in Malaysia
}

\begin{abstract}
The increase usage and employment of Social Media Technologies (SMTs) in personal, business and education activities is credited to the advancement of Internet broadband services, mobile devices, smart phones and web-based technologies. Informatics programs are technological-oriented in nature, hence students and academics themselves would arguably be quite adept at using SMTs. Students undertaking Informatics programs are trained to thrive in challenging, advanced technical environments as manifestations of the fast-paced world of Information Technology. Students must be able to think logically and learn "how to learn" as "knowledge upon demand" is one of the expected capabilities of Informatics graduates. This rapid change in knowledge and skill sets requires learners to not only be lifelong learners, but to be constantly connected to the field of computing science. SMTs may be the conduit that supports these needs. Despite being an Information and Communication Technology (ICT) hub and having advanced ICT Infrastructure nationally, the use of social media beyond young people in Malaysia for education purposes is still relatively new and little is known about the user experience, intentions, perceptions and acceptance of these technologies by students. This paper reports on a workin-progress that investigates the perceptions, acceptance, usage and access to social media by undergraduate Informatics students in higher education institutions in Malaysia.

Preliminary findings from 331 responses collected from an online questionnaires administered to students, academics and administrators from Informatics and Non-Informatics programs show that whilst students reported SMTs use mainly for personal social activities, the data from online questionnaires show that many students and instructors have started to explore and accept the use of SMTs as a tool for engaging with their Institution and their peers as well as for teaching and learning purposes. The paper also presents a conceptual model based on Connectivism and Communities of Practice (CoP) that has been developed to inform the study in terms of the role SMTs can play in building virtual learning communities. The intended outcome from this study is the development of a design framework for implementing SMTs as supporting tools for student engagement and to inform future practice.
\end{abstract}

\section{Keywords}

social, media, technologies, undergraduate, engagement, informatics, malaysia, students, academic, purpose

Disciplines

Education | Social and Behavioral Sciences

\section{Publication Details}

See Yin Lim, J., Agostinho, S., Harper, B. \& Chicharo, J. (2014). The engagement of social media technologies by undergraduate informatics students for academic purpose in Malaysia. Journal of Information Communication and Ethics in Society, 12 (3), 177-194. 


\title{
THE ENGAGEMENT OF SOCIAL MEDIA TECHNOLOGIES BY UNDERGRADUATE INFORMATICS STUDENTS FOR ACADEMIC PURPOSE IN MALAYSIA
}

\author{
Jane See Yin Lim (janesy.lim@newinti.edu.my)1, Shirley Agostinho (shirleya@uow.edu.au)2, \\ Barry Harper (bhaper@uow.edu.au) and Joe F Chicharo (Chicharo@uow.edu.au)² \\ ${ }^{1}$ INTI International College Subang, Malaysia \\ ${ }^{2}$ University of Wollongong, Australia
}

The increase usage and employment of Social Media Technologies (SMTs) in personal, business and education activities is credited to the advancement of Internet broadband services, mobile devices, smart phones and web-based technologies. Informatics programs are technological-oriented in nature, hence students and academics themselves would arguably be quite adept at using SMTs. Students undertaking Informatics programs are trained to thrive in challenging, advanced technical environments as manifestations of the fast-paced world of Information Technology. Students must be able to think logically and learn "how to learn" as "knowledge upon demand" is one of the expected capabilities of Informatics graduates. This rapid change in knowledge and skill sets requires learners to not only be lifelong learners, but to be constantly connected to the field of computing science. SMTs may be the conduit that supports these needs. Despite being an Information and Communication Technology (ICT) hub and having advanced ICT Infrastructure nationally, the use of social media beyond young people in Malaysia for education purposes is still relatively new and little is known about the user experience, intentions, perceptions and acceptance of these technologies by students. This paper reports on a work-in-progress that investigates the perceptions, acceptance, usage and access to social media by undergraduate Informatics students in higher education institutions in Malaysia.

Preliminary findings from 331 responses collected from an online questionnaires administered to students, academics and administrators from Informatics and Non-Informatics programs show that whilst students reported SMTs use mainly for personal social activities, the data from online questionnaires show that many students and instructors have started to explore and accept the use of SMTs as a tool for engaging with their Institution and their peers as well as for teaching and learning purposes. The paper also presents a conceptual model based on Connectivism and Communities of Practice (CoP) that has been developed to inform the study in terms of the role SMTs can play in building virtual learning communities. The intended outcome from this study is the development of a design framework for implementing SMTs as supporting tools for student engagement and to inform future practice.

\section{KEYWORDS}

Social Media Technologies (SMTs), Social Media, Connectivism, Communities of Practice (CoPs), Informatics Programs, Higher Education

\section{INTRODUCTION}

This paper reports a work-in-progress research project that is examining how social media is perceived and used by both students and academics in the Malaysian Higher Education Context. Knowledge of how university students use technology will help higher education institutions to better support effective decisions on the adoption of technology for higher education (Corrin L, Bennett S, and Lockyer L, 2010). With particular reference to the use of social media, very little work has been reported on student and academic engagement, their perspectives and perceived effectiveness of social media usage in higher education especially in the Malaysia context. A range of research has reported on students' perception and usage of social media and digital technologies to support their learning (eg., Hrastinski and Aghaee, 2011, Margaryan, LittleJohn and Vojt, 2010, Bennett \& Maton, 2010) but much of this work has focused on quantitative research with students from universities in United States and Australia, with an emphasis mainly on student's perception and acceptance.

There are calls for more research to examine how social media is perceived and accepted by students and academics for teaching and learning purposes (Shittu, Madarsha and Tunku Ahmad, 2011). This study will specifically add to knowledge of student perceptions and acceptance of social media by reporting on the 
perceived benefits students may gain through the use of social software, faculty perceptions in integrating social software into the curriculum, student's demographic factors and usage hours of social software that affect their general performance, and effective methods of using social software to support student learning and engagement with their institutions. This study seeks to address these questions and start to fill our gap in knowledge of these issues and address the reported mismatch between the beliefs of higher education institutions about student use of social media and the reality. The outcomes will be of value to these institutions as they develop policies and respond to these issues pedagogically.

\section{SOCIAL MEDIA TECHNOLOGIES (SMTs)}

A Social Media Technologies (SMT) is generally a portable web-enabled tool or technology, which is accessible through platform independent web browsers that emphasize social activities for collaboration, communications, community and creativity (Joosten 2012, Dabbagh \& Kitsantas, 2012). SMTs enable the sharing of collaborative activities not only in social but also in educational, and, now increasingly, in business contexts. It is believed that through these shared and networked activities, users will become creators of collaborative knowledge that forms a collective intelligence. Levy (1999) cited by Nielsen (2010) defined collective intelligence as "a form of universallyBe distributed intelligence, constantly enhanced, coordinated in real time, and resulting in the effective mobilization of skills...No one knows everything, everyone knows something..."(p 1). Collective Intelligence is not something new but the capability of social media software to pull together all the knowledge harnessed through collaborative activities makes the process more accessible to learners.

Generally, Social Media Technologies (SMTs) can be grouped into seven categories; text-based, media sharing, social networking, mobile-based applications, virtual world and games, synchronous communications and conferencing applications, and mashups. All these tools have different functionalities and purposes to suit the needs of students in this digital environment with the tools giving students the ability to set up their own personal learning communities within the Internet environment which would allow them to stay connected in the topic of their interest. Students can take advantage of these various functionalities in their own personal learning communities. For example, students could use text-based applications such as blogs, wikis, and discussion forums for their individual or group assignments and projects. Students could also use social networking websites such as Facebook, Ning, and more to get connected with their friends, family, and lecturers. Students are spoilt with choices and availabilities of these tools which they can harness and use not only for entertainment purpose but also for their academic purpose. In addition, most of these are now easily accessible via their smart phones and hand-held portable devices.

There has been an explosion in the use of social media across many contexts, e.g., marketing, advertising, recreation, banking, recruitment, education, etc). The continuous growth and expansion of the World Wide Web, the move internationally by many countries towards knowledge economies, the need for globalization and the advancement of new technologies are all factors that have led to the need to reconsider the current pedagogies and engagement mechanisms adopted for teaching and learning in higher education. Because students in the digital age are heavily exposed to various emerging technologies and the vast amount of information which they can access from anywhere at any time, the role of higher education institutions now might be to focus on helping students to re-configure their knowledge as well as produce new knowledge. As such, there is a need to innovate current educational practices and explore new learning paradigms that could address the learning needs for the $21^{\text {st }}$ Century (Brown, 2006). Tapscott (2008) stated that "in education the net generations are forcing a change in the model of pedagogy, from a teacher-focused approach based on instruction to a student-focused model based on collaboration” (p. 11).

However, despite claims by researchers such as Frand (2000) that immersion in these technologies is so complete that young people do not even consider computers as 'technology' any more, recent studies have also shown that access to these technologies is not universal and that more recent mobile technology use for learning by young people at university level is quite limited (Bennett, Maton and Kervin 2008, Kvavik, 
Caruso \& Morgan, 2004, Kennedy, Krause, Judd, Churchward \& Gray, 2006) and not necessarily productive (Hrastinski and Aghaee, 2011). Evidence is also now emerging that there are cultural differences in use of these technologies (Kennedy, Judd, Dalgarno and Waycott, 2010). It would be a mistake, in any technology policy implementation context to not recognise the variation in technology skills of learners and staff, and it cannot simply be assumed all learners are skilled 'digital natives and all academics are skilled technology users or that institutions are supporting these trends.

There is a perception that social media applications have the ability to help students improve their learning by engaging them in informal learning activities and processes. Siemens (2004) described informal learning as one of the significant trends in learning. Cluett and Skene (2007) add that social software can be used to encourage critical thinking, team work, creativity and self-paced learning among students, and these skills in turn, help students to develop deep learning approaches. Bartlett-Brag (2006) argues that use of these emerging technologies can stimulate the capture of tacit knowledge from informal learning situations. Dabbas and Kitsantas (2012) reported that social media can help to facilitate the creation of Personal Learning Environments (PLEs), which empower students to take charge of their own learning by selecting, creating and organizing tools and resources that help in effective and efficient learning (Rubin 2010, and McLoughlin \& Lee, 2010). Dabbas and Kitsantas (2012) added that within student's own PLEs, they can aggregate and share the results of their learning achievements, participate in collective knowledge generation, and manage their own meaning making. The PLEs with the support of social media can be regarded as a platform to integrate the informal and formal learning in the higher education context.

Many instructors of higher education institutions have started to explore technology that can mediate and enhance their teaching as well as promoting active learning for students (Anderson, 2007; Eijkman, 2008; McLoughlin \& Lee, 2010; Selwyn, 2010). Tess (2013) suggested instructors to not only concentrating on the practical integration of technology into the courses, but also to focus on the theoretical framework for implementing the technology as a learning resource. Yet, the focus on theoretical framework has not been given much emphasis by the instructors in higher education institution (Merchant, 2012).

Despite the increase in the use of social media in education, very little research has been done to explore social media use in universities in the Asia-Pacific region with even less exploring theories to frame this use. Studies have reported that generally in Asia Pacific countries, most educators are using social media as informal collaboration tools, mainly for social networking and communication purposes, rather than using it as part of the teaching and learning process. This study aims to develop a better understanding of where South East Asia, and in particular Malaysia is placed with taking advantage of the opportunities social media offer, it will be essential to understand the current use of social media and student and academic perception of this use. Current research that highlights the use of Social Media Technologies in Higher Education Institutions in Malaysia is very limited and none are focusing on Informatics students' usage of social media technologies or making use of a conceptual framework to help explain the outcomes. For example, research has been reported on the use of social media technologies that focused on personality traits of students (Abdul Hamid N, Ishak M. S, Ismail S.A and Mohmad Yazam S.Y.N, 2013), use of Social Networking Sites among Malaysian university students for informal learning (Hamat A, Embi M. A, and Abu Hasan H, 2012a), study on the impact of social media use on academic performance among university students (AlRahmi W.M, and Othman M. S, Undated), a study on the improvement of students' academic performance by using social media through collaborative learning in Malaysian Higher Education, focusing on one specific university (Al-Rahmi W.M, Othman M. S, and Musa N.A, 2014), and study on how top-performing students’ use of Social Networking Sites (Hamat A, Embi M. A, and Abu Hasan H, 2012b), etc).

This study will explore this issue by considering the conceptual frameworks of Communities of Practice (CoPs) by Ettiene Wenger (1998) and Connectivism proposed by George Siemen (2004), which have been popularly linked as a theoretical explanation for the use of social media, to propose a conceptual model (explained below) for social media implementation in higher education institutions. 


\section{CONCEPTUAL MODEL TO GUIDE THE RESEARCH STUDY}

A conceptual model that integrates the characteristics of Community of Practice Theory (CoP) developed by Ettiene Wenger (1998), and Connectivism (a proposed learning theory advocated by George Siemens (2004)) has been developed to inform the study in terms of how Social Media Technologies (SMTs) can play a role in building a virtual learning community in Higher Education Institution. The conceptual model also helped to guide the study by informing the coverage of the study, the type of questions to be asked and who the study should focus on.

Connectivism and Communities of Practice (CoPs) can be used to complement each other as both emphasize on social learning and learning through collective intelligence. Jo Bloggs (2005, para 6) in her blog writes "Wenger states that the collective is necessary simply because 'domains' are too complex for one individual to master while Siemens claims that the differing perspectives brought together by nodes in the same network are necessary for exploring ideas and attaining meaning from knowledge (Siemens, 2004)”. Both Connectivism and Communities of Practice (CoPS) theories promote informal learning and consider learning experiences among peers as equally valuable as learning in the formal setting (Giesbrecht, 2007). In Connectivism, students formed many connections and actively participated in the network which makes up the learning community. Siemens (2007) added that learning is a continual process which can occur in different settings including communities of practice, personal networks and work place task.

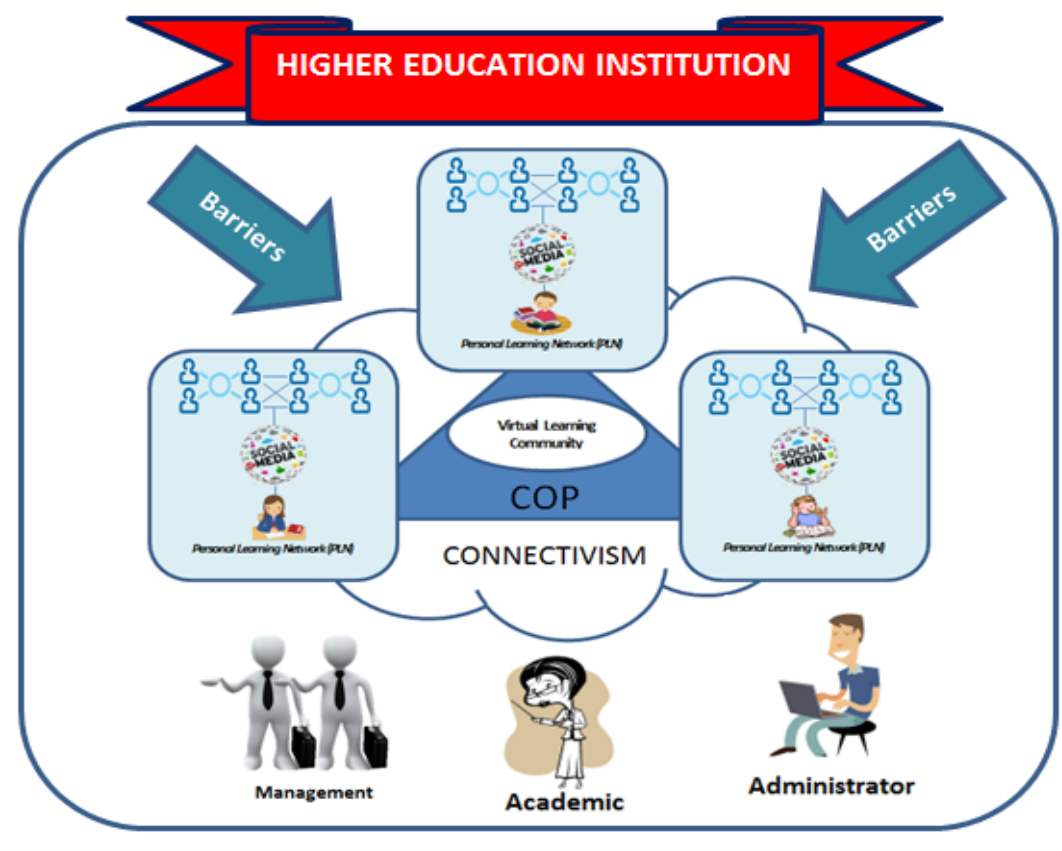

Figure 1. Proposed Conceptual Model

The conceptual model in Figure 1 above was developed to guide the research process and interpret the data from within the theoretical context. The conceptual model proposed was developed by drawing on Community of Practice (CoP) as the building blocks of the virtual learning community for Higher Education Institutions and overlaying Connectivism principles where students are building their own Personal Learning Networks (PLNs) which are interconnected to form the virtual learning community within the specific domain or area of study. This PLN is an informal learning platform for students in which they connect, interact and communicate with people, their peers, professionals, etc in their own personal learning environment. Each PLN might be connected to one or more than one virtual learning communities, within or outside the respective institution. These wide connections of networks enable students to source vast amount of resources that could contribute to the knowledge development activities within each learning community. The effective sharing and sourcing of information in the entire network could be achieved through the 
connections supported and established via the use of Social Media Technologies (SMTs). Figure 1 then represents visual the combination of these two positions as described above, with Community of Practice the control component and Connectivism the enabling principles.

SMTs are used as the tools to provide the environment for students to stay connected, to facilitate the growth of the network and to strengthen the community. The adoption of SMTs for teaching and learning activities will not be successful without the support from the top management, academics and administrators of the institution. Boitshwarelo (2011) concluded that online communities of practice are necessarily a manifestation of connectivism and the formation and functioning of the communities of practice allows connectivism to take its course. The social characteristics of Connectivism and Communities of Practice (CoPs) with the support of Social Media Technologies (SMTs) make life-long learning possible. With the clear identification and understanding of the barriers and critical success factors, the implementation of the proposed virtual learning communities has the potential to be effective and the outcomes will be desirable. This conceptual model will be mapped against the students reported interactions to help to understand their engagement process and to help to interpret the data collected.

\section{RESEARCH METHODOLOGY}

The central research question that guides this study is "How are Higher Education students in Malaysia engaging with SMTs within their university experience?” The central research question is then further broken into four specific research questions: How does this engagement manifest itself in the teaching and learning? How does this engagement manifest itself in students' relationship with their institution? How do these students perceive these engagements? Does the engagement of Informatics students differ from other disciplines?

A mixed-method research methodology with a significant survey research component was employed for this research. This methodology focused on collecting and analyzing quantitative and qualitative data to better understand the research problems. For this study, a Mixed Method Sequential Transformative Research Strategy based on a QUAN $\rightarrow$ Qual model was used in the data collection process. This strategy has two distinct data collection phases in which the main priority or emphasis was given to the quantitative phase, while the results from the quantitative data collection will be used to further inform the secondary data collection (Creswell, 2003). The Transformative Research Strategy has a theoretical lens overlaying the sequential procedures to guide the study. In this context, the theoretical lens will be the conceptual model discussed earlier which was used to inform and guide the research, and help to shape the direction, research questions and research instruments. In this QUAN $\rightarrow$ Qual model, quantitative data collection involved anonymous online questionnaires which administered to students, academics, and administrators from both Informatics and non-informatics undergraduate programs in Malaysia. The survey sought to investigate their exposure and use of social media technologies for engagement, teaching and learning. The questions in the online questionnaires were divided into several sections, e.g. demographic, general experience in using social media technologies, and experiences of using social media technologies for academic purposes (including benefits, limitations and barriers). In order to achieve the targeted number of participants for this research, a website with the invitation of participations and the links to the online survey was created. All the participants for this study were then recruited via emails, Facebook Communities and Universities / Colleges Online Support Groups in which the link of the website was attached and shared. Students were also recruited in collaboration with academics in the participated institutions, by approaching students directly through email or Social Media Technologies such as Facebook. The benefits of creating the website and putting the surveys online enable it to be forwarded to many people at the same time. In addition, by posting the website and survey links on Facebook, it enabled it to be shared by many people in the social network. The links for the online surveys were opened for 2 months before it was closed for analysis. Multiple emails and Facebook reminders were sent out to remind participants to do the anonymous online surveys. 
The data collection process of a questionnaire was followed by qualitative collection of data in which the same voluntary Informatics students were interviewed to better understand their needs, usage and experiences in using social media technologies for their classes. Face-to-face interviews were conducted on participants who expressed their interest when they filled in the online questionnaires earlier. The questions in the interview generally cover more in depth the participant's experiences in using SMTs for academic purposes. During the interview session, the academics will also be asked about their willingness to also participate in the observation activities, in which the researchers will be allowed to observe how the academics use SMTs in their classes. The objectives of the observations are to observe how SMTs are being used effectively by both lecturers and students for teaching and learning, and how students engage with their peers and their lecturers. The observations will start in April 2014 and will go on for about 2 months.

Mixed-method research methodology is considered to be most appropriate for this study as it allows the researchers to gather multiple forms of data from diverse audiences such as educators, administrators and students. The area of study is relatively new and both empirical and descriptive data will be needed to address the research questions because of the lack of underlying understanding of the use of SMTs in higher education. Specifically, students undertaking Informatics Programs in Malaysia were surveyed and interviewed to identify and document their exposure and usage of social media technologies to support their learning. Non-Informatics students were surveyed to understand the differences of social media usage compared to Informatics students. Academics teaching in Informatics and Non-Informatics programs were also surveyed to articulate and document their adoption and implementation of social media technologies for their classes. Lastly, administrators from higher institutions in Malaysia were surveyed and interviewed to understand how the institutions are adopting and supporting social media technologies and what policies are driving this process.

For this study, descriptive statistics are being used with the aim to summarize the samples, rather than use the data to learn about the population that the samples of data are thought to represent. Thus, the chosen sample size will not be based on any probability theory, but a comfortable and reasonable sample representation for each category. Because of the large number of higher education institutions across Malaysia and the existence of public and private institutions, a representative sample of academic and student responses will require sampling from a range of institutions and the intentions is to maintain a reasonable sample size for each institution to ensure the data is representative.

This study is on-going with online-questionnaires and most interviews completed to date. The observation of Social Media practices by academic and students has yet to be conducted and thus, the outcomes will not be discussed in this paper.

\section{PRELIMINARY RESULTS}

\subsection{Demographic data}

As of April 2013, there are 20 public universities, and 62 private universities, university colleges, and colleges in Malaysia (www.visachannels.com). Based on the statistics provided by the Ministry of Higher Education Malaysia (www.mohe.gov.my), as of December 2011, there are 383 higher education institutions in Malaysia, and the total enrolments for undergraduate students is 1,049,885. There were 122,517 students enrolled in the Science, Maths and Computing Cluster.

This paper focuses on the quantitative data collected from the study participants on their engagements and use of Social Media Technologies in Malaysia Higher Education Institutions. In total, there were 111 Informatics students, 106 non Informatics Students, 38 Informatics Academics, 33 Non Informatics Academics and 43 Administrators who responded to the online questionnaire. Figure 2 shows the distribution of respondents and the total number of respondents. For the purpose of this paper, the data analysis focuses on student engagement and use of Social Media Technologies in their tertiary studies. 


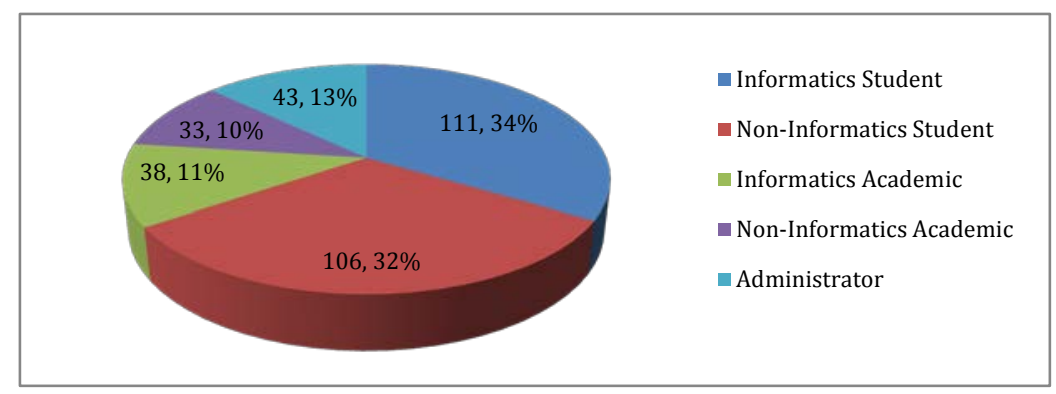

Figure 2: Total number of respondents

The age group of both the Informatics and Non-Informatics students is shown in Figure 3 as follow. The majority of the students are from the age group of 21 to 22 (34.91\% for Informatics and $44.23 \%$ for Non-Informatics).

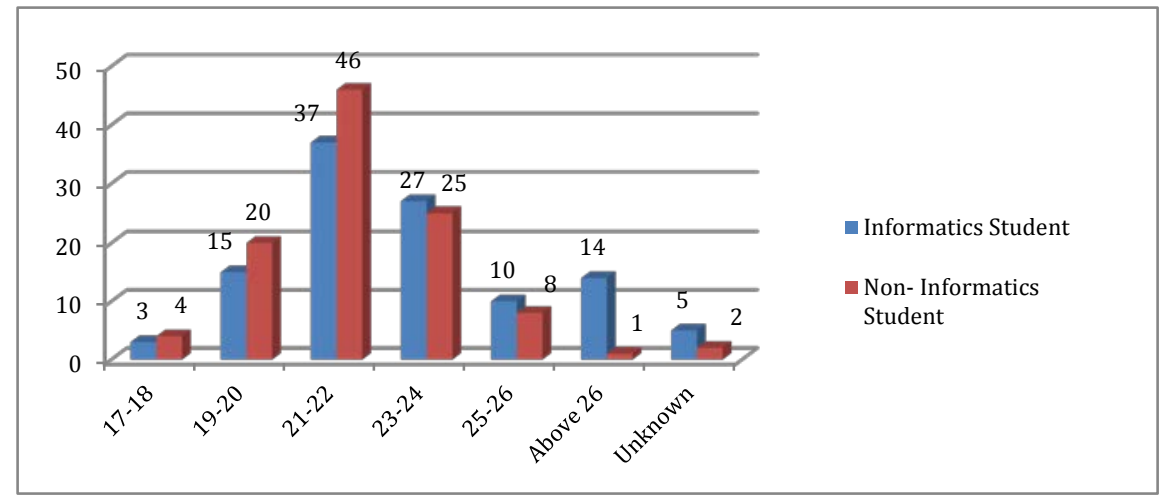

Figure 3: Age of the respondents

The gender of the participants between Informatics and Non-Informatics is closely matched. There are 80 Informatics male students and 31 Informatics female students, compared to 78 Non-Informatics male students and 28 Non-Informatics female students. Out of the 111 Informatics students, $81.9 \%$ are Malaysian while for Non-Informatics, 95.2\% (101 out of 106) of the respondents are Malaysian. Non Malaysian students are mainly from Indonesia, China, India, Iraq, Mauritius, Botswana, and Nepal. About $75 \%$ of the respondents are currently studying in private universities or private university colleges in Malaysia (Refer to Figure 4: Institution of study)

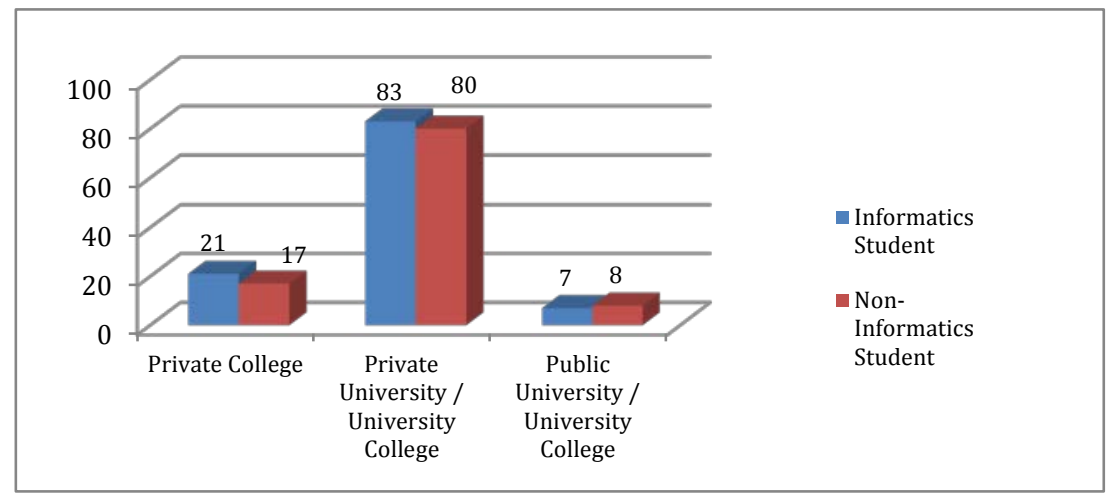

Figure 4: Institution of Study

For the level of study, about $85 \%$ of the respondents are currently undertaking a Degree programs in their Institution. Figure 5 depicts the breakdown of the level of study of the respondents. 


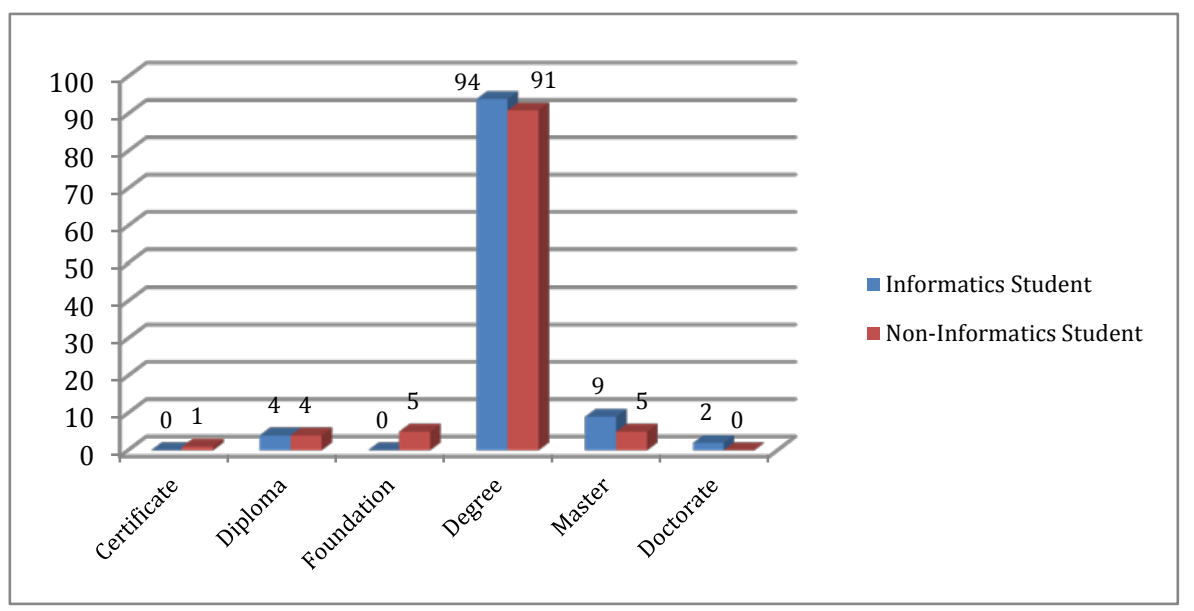

Figure 5: Level of Study

\subsection{Social Media Exposure}

This section of the paper compares the digital devices ownership and social media exposures and experiences between Informatics and Non-Informatics students. The purpose of the comparative studies is to understand whether there is a difference between the two group of students in terms of their exposures and experiences in using Social Media Technologies in the course of their study. From Figure 6 below, it shows that $97.3 \%$ of the Informatics students and $94 \%$ of the Non-Informatics students owned a laptop or notebook, with about $90 \%$ of them owning smartphones. The ownership of digital tablets is surprisingly not that high, i.e. below $38 \%$.

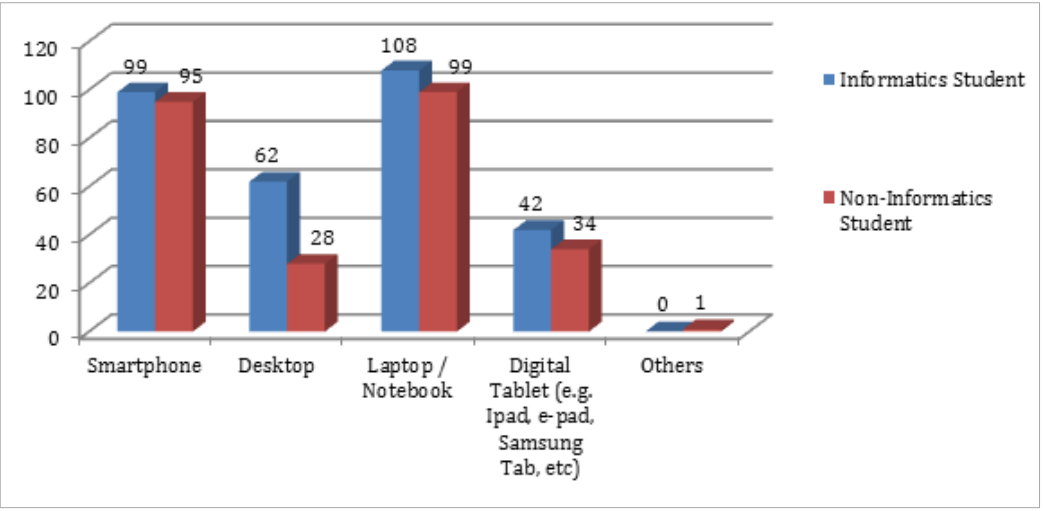

Fiqure 6: Ownership of digital devices

The data collected shows that the majority of the students, irrespective of discipline of study, spent more than 6 hours daily online (Table 1). When asked about the use of Social Media Technologies (SMTs), only less than $10 \%$ of the respondents (Table 2) claimed that they are not using Social Media Technologies (SMTs).

\begin{tabular}{|c|c|c|}
\hline Hours & Informatics Students & Non-Informatics Students \\
\hline$<1$ hour & $1(0.91 \%)$ & $2(1.90 \%)$ \\
\hline $1-2$ hours & $6(5.45 \%)$ & $8(7.62 \%)$ \\
\hline $3-4$ hours & $22(20 \%)$ & $18(17.14 \%)$ \\
\hline $5-6$ hours & $26(23.64 \%)$ & $38(36.19 \%)$ \\
\hline$>6$ hours & $55(50 \%)$ & $40(38.1 \%)$ \\
\hline
\end{tabular}

Table 1: Hours spent online daily 


\begin{tabular}{|c|c|c|}
\hline Do you use SMTs? & Informatics Students & Non-Informatics Students \\
\hline Yes & $100(90.09 \%)$ & $100(94.34 \%)$ \\
\hline No & $11(9.91 \%)$ & $6(5.66 \%)$ \\
\hline
\end{tabular}

Table 2: General use of Social Media Technologies (SMTs)

The top three popular Social Media Technologies (SMTs) used by the respondents are Social Networking Websites (about 99\%) followed by Media Sharing tools (about 92\%) and Mobile Messaging applications (about $85.3 \%$ for Informatics and 92\% for Non-Informatics). The detailed breakdown is shown in Table 3: Social Media Technologies exposures.

\begin{tabular}{|c|c|c|}
\hline Social Media Technologies & $\begin{array}{c}\text { Informatics Students } \\
\text { (95 Respondents) }\end{array}$ & $\begin{array}{c}\text { Non-Informatics } \\
\text { Students } \\
\text { (95 Respondents) }\end{array}$ \\
\hline Social Networking Websites (e.g. Facebook, Ning, Google+, LinkedIn, etc) & $(98.95 \%) 94$ & (98.95) 94 \\
\hline Media Sharing Tools (e.g. YouTube, Flickr, Dropbox, SlideShare, Instagram, Pinterest, etc) & (91.58\%) 87 & $(91.58 \%) 87$ \\
\hline Blogs (e.g. Blogger, Wordpress, eBlogger, LiveJournal, Elgg, etc) & $(35.79 \%) 34$ & (35.79\%) 34 \\
\hline Wikis (e.g. Wikipedia, Wikias, Wikispaces, PBWikis Wikiversity, etc) & $(69.47 \%) 66$ & $(62.11 \%) 59$ \\
\hline Micro-Blogging (e.g. Twitter, Sina Weibo, Tumbler, Plurk, Qaiku, etc) & $(36.84 \%) 35$ & $(41.05 \%) 39$ \\
\hline Social Bookmarking (e.g. Digg, Reddit, StumbleUpon, Delicious, Furl, etc) & $(6.32 \%) 6$ & $(4.21 \%) 4$ \\
\hline RSS Feeds (e.g. TweetDeck, Flock, FriendFeed, Netvibes, Radian6, etc) & $(13.68 \%) 13$ & $(1.05 \%) 1$ \\
\hline $\begin{array}{l}\text { Mobile Messaging Apps (e.g. Whatsapp, Line, eBuddy XMS, Skype, DimDim, } \\
\text { GoogleTalk, Tokbox, etc) }\end{array}$ & $(85.26 \%) 81$ & (91.58\%) 87 \\
\hline $\begin{array}{l}\text { Synchronous Communication \& Conferencing (e.g. Messenger, Skype, DimDim, } \\
\text { Tokbox, Google Talk, etc) }\end{array}$ & $(76.84 \%) 73$ & $(70.53 \%) 67$ \\
\hline Others & $(1.09 \%) 1$ & 0 \\
\hline
\end{tabular}

Table 3: Social Media Technologies exposures

\subsection{Social Media Technologies Use for Academic purposes by Informatics Students}

This section covers the use of Social Media Technologies (SMTs) by Informatics students for academic purpose. About $90 \%$ of the Informatics students claimed that they have started to use SMTs for academic purpose (Refer to Table 4) and the main purposes of using SMTs are for assignments or project collaboration (about 98\%), and for sharing of documents (90-92\%). Table 5 depicts the use of SMTS in supporting students' academic activities. There is little difference in usage between Informatics and Non-Informatics students. The top three SMTs that they used to support their studies are Social Networking Websites such as Facebook (96.39\%), followed by Wikis such as Wikipedia (73.49\%), and Media Sharing Tools such as YouTube and Dropbox (69.88\%). Table 6 shows the type of SMTs used for academic purpose.

\begin{tabular}{|c|c|c|}
\hline $\begin{array}{c}\text { Do you use SMTs for } \\
\text { Academic purpose }\end{array}$ & $\begin{array}{c}\text { Informatics Students } \\
\text { (91 Respondents) }\end{array}$ & $\begin{array}{c}\text { Non-Informatics Students } \\
\text { (97 Respondents) }\end{array}$ \\
\hline Yes & $85(90.43 \%)$ & $87(89.69 \%)$ \\
\hline No & $9(9.57 \%)$ & $10(10.31 \%)$ \\
\hline
\end{tabular}

Table 4: Use of Social Media Technologies (SMTs) for Academic Purpose

\begin{tabular}{|l|r|c|}
\hline How do you use SMTs to support your studies? & $\begin{array}{c}\text { Non-Informatics } \\
\text { Students } \\
\text { Informatics Students } \\
\text { (80 Respondents) }\end{array}$ & $\begin{array}{c}\text { Respondents) } \\
\text { (82 Rend }\end{array}$ \\
\hline Assignments / Project Collaboration Discussions & $81(97.59 \%)$ & $80(97.56 \%)$ \\
\hline Sharing of documents & $76(91.57 \%)$ & $74(90.24 \%)$ \\
\hline Knowledge / Information Sharing & $69(83.13 \%)$ & $70(85.37 \%)$ \\
\hline Activities / Event updates & $67(80.72 \%)$ & $69(84.15 \%)$ \\
\hline Sourcing for information & $60(72.29 \%)$ & $67(81.71 \%)$ \\
\hline Communicating with Instructors, lecturers, professors, and peers & $73(87.95 \%)$ & $70(85.37 \%)$ \\
\hline
\end{tabular}

Table 5: Use of SMTs in supporting the academic activities 


\begin{tabular}{|l|c|}
\hline \multicolumn{1}{|c|}{ Social Media Technologies For Academic Purpose } & $\begin{array}{c}\text { Informatics Students } \\
\text { (83 Respondents) }\end{array}$ \\
\hline Social Networking Websites (e.g. Facebook, Ning, Google+, LinkedIn, etc) & $96.39 \%(80)$ \\
\hline Media Sharing Tools (e.g. YouTube, Flickr, Dropbox, SlideShare, Instagram, Pinterest, etc) & $69.88 \%(58)$ \\
\hline Blogs (e.g. Blogger, WordPress, eBlogger, LiverJournal, Elgg, etc) & $20.48 \%(17)$ \\
\hline Wikis (e.g. Wikipedia, Wikias, Wikispaces, PBWikis, Wikiversity, etc) & $73.49 \%(61)$ \\
\hline Micro-Blogging Tool (e.g. Twitter, Sina Weibo, Tumblr, Plurk, Qaiku, etc) & $9.64 \%(8)$ \\
\hline Social Bookmarking Tool (e.g. Digg, Reddit, StumbleUpon, Delicious, Furl, etc) & $6.02 \%(5)$ \\
\hline RSS Feeds (TweetDeck, Flock, FriendFeed, Netvibes, Radian6, etc) & $4.82 \%(4)$ \\
\hline Mobile Messaging applications (e.g. WhatsApp, Line, eBuddy XMS, Meebo, WeChart, etc) & $53.01 \%(44)$ \\
\hline $\begin{array}{l}\text { Synchronous Communication \& Conferencing (e.g. Messenger, Skype, DimDim, Tokbox, Google } \\
\text { Talk, etc) }\end{array}$ & $44.58 \%(37)$ \\
\hline Others & $1.20 \%(1)$ \\
\hline
\end{tabular}

Table 6: Type of SMTs used for academic purposes

Students were also asked how their instructors or lecturers used the Social Media Technologies in their classes, and $80.5 \%$ said that their instructors are using SMTs as a communication tool to communicate with the students, followed by $79.3 \%$ said it was used for assignment collaboration and discussion, and $78 \%$ said it was used for sharing of documents. Table 7 illustrates the differences between student's academic use of SMTs versus their instructor's use of SMTs to support teaching and learning activities.

\begin{tabular}{|l|c|c|}
\hline How do you use SMTs to support your studies? & How students use SMTs & $\begin{array}{c}\text { How instructors use } \\
\text { SMTs }\end{array}$ \\
\hline Assignments / Project Collaboration / Discussions & $81(97.59 \%)$ & $79.27 \%(65)$ \\
\hline Sharing of documents & $76(91.57 \%)$ & $78.05 \%(64)$ \\
\hline Knowledge / Information Sharing & $69(83.13 \%)$ & $67.07 \%(55)$ \\
\hline Activities / Event updates & $67(80.72 \%)$ & $73.17 \%(60)$ \\
\hline Sourcing for information & $60(72.29 \%)$ & $42.68 \%(35)$ \\
\hline Communication & $73(87.95 \%)$ & $80.49 \%(66)$ \\
\hline
\end{tabular}

Table 7: Students Vs. Instructors Usage of SMTs in Teaching and Learning

When asked about the perceived benefits of using SMTs in supporting teaching and learning activities, students listed SMTs as an enabler for information / knowledge sharing (93.98\%), followed by supporting innovative teaching methods, and enabling cooperative and collaborative work (both 73.49\%). Table 8 listed the student's perceived benefits of using SMTs for academic purpose.

\begin{tabular}{|l|l|}
\hline SMTs support innovative teaching methods & $73.49 \%$ \\
\hline SMTs support peer-to-peer learning & $71.08 \%$ \\
\hline SMTs enhance student motivation & $50.60 \%$ \\
\hline SMTs improve student's participation & $67.47 \%$ \\
\hline SMTs enable information / knowledge sharing & $93.98 \%$ \\
\hline SMTs enable cooperative and collaborative work & $73.49 \%$ \\
\hline SMTs support the creation of personal learning environment & $53.01 \%$ \\
\hline SMTs strengthen lecturers and students rapport & $63.86 \%$ \\
\hline
\end{tabular}

Table 8: Perceived benefits of using SMTs for academic purpose

Aside from the benefits reported, students also listed SMTs as the main detractor that causes distraction and loss of focus in their studies (66.7\%). Refer to Table 9 for the list of barriers in using SMTs. They also attributed the blocking of some SMTs applications by the university or colleges (81.48\%) as the main restrictions that hinder them from using SMTs to support their studies. 


\begin{tabular}{|l|c|}
\hline Slow Internet connections / Low Bandwidth & $62.96 \%$ \\
\hline Blocking of some applications by the university & $81.48 \%$ \\
\hline All activities were being monitored & $38.27 \%$ \\
\hline Social Media accounts being hacked & $22.22 \%$ \\
\hline Privacy issues & $44.44 \%$ \\
\hline Others & $1.23 \%$ \\
\hline
\end{tabular}

Table 9: Restrictions encountered in the use of SMTs in the Institution.

Almost 55\% of the respondents claimed that they are not sure whether there is any Social Media Policy within their institution of study. Only 28\% of them said that there is a Social Media Policy within their Institution and $17 \%$ said there is no Social Media Policy in their Institution. Finally, students were asked whether they will actively participate and contribute to the learning communities in the event that their instructors decided to adopt Social Media Technologies as the tools to support teaching and learning activities in class and $44.4 \%$ of them said they will participate actively, while $55.6 \%$ said they might consider participating.

\section{DISCUSSION}

From the data collection and initial analysis, there does not appear to be a significant difference in the ownership and use of SMTs by students from Informatics and Non-Informatics background despite the heavy exposure of technologies by the Informatics students. The amount of hours spent online, the types of SMTs used and the pattern of usage are all quite closely matched. Thus, the perception that relates Informatics students to the high ownership of technology devices and high usage of online applications and Social Media Technologies might not be relevant. The students surveyed reported that they mainly use Social Media Technologies (SMTs) for personal social activities, but from the data collected from the questionnaires, it does shows that many students and instructors have started to explore and accept the use of SMTs as a tool for engaging with their Institution and their peers as well as for teaching and learning purposes. The successful adoption of SMTs in higher education institutions will depend on many factors. Students, academics and the institutions themselves will all have views and practices that are not necessarily align. Thus, innovative institutions need to understand the critical success factors and the barriers that restrict the implementation of SMTs within the Higher Education Institution in order to take advantage of the opportunities offered by SMT's in higher education.

It is premature to make use of the conceptual model proposed to explain these results as the data reported here represents the initial survey data collected. However initial indications are that what Wenger calls collectives appear to be central to student use of social media and the reported use of multiple tools depending on the context as well as linking of the tools contents appear to be illustrating the engagement component of Connectivism.

\section{LIMITATIONS}

This study is limited in a number of ways. The use of surveys has some limitations in that respondents may give answers they perceive are appropriate, rather than their specific experience. The use of interviews and focus group discussions does help to reduce this limitation as the researcher is able to probe issues where the survey data may not be specific enough. The study is focused on diploma and degree students who study Informatics related programs in Malaysia. Care would need to be taken in applying the findings to other programs and countries and the higher degree contexts may give entirely different results. Additionally, in any such study participant numbers can be a limitation. In this study, the participant numbers are limited firstly because of the category size and secondly due to the survey response size. 


\section{CONCLUSION}

Higher education in the $21^{\text {st }}$-Century is in the process of change. Students in this generation are heavily exposed to digital technologies and the Internet and many misconceptions about their ability and use are prevalent within higher education (Bennett, Maton and Kervin, 2008). The extensive use of the Internet and social media has the potential to offer new types of student engagement and educational settings. The use of social media in higher education is becoming critical as the use of these tools and technologies are becoming part and parcel of current student's lifestyles. Higher education institutions need to take this opportunity to harness these technologies that are already integrated into students' daily lives to design an innovative and creative education environment that will enhance and improve their learning experiences. Research is showing that social media can be supportive of student learning, but there is limited knowledge on how it is being used and the outcomes of using it within educational settings. There is wide range of social media usage in educational settings now being reported, but many issues are still unexamined. Limited studies have been focusing on the educators' readiness, acceptance or refusal in integrating social media into their courses, the perceived effectiveness of the tools and student outcomes for their learning. Additionally, there has been limited research reported on examination of theoretical frameworks through which to examine and develop understandings of the contexts of use of SMTs in Education.

The preliminary analysis shows that there are no significance differences between the Informatics and NonInformatics students in term of the ownership of digital devices, hours spent online, use of SMTs, etc, despite their heavy exposure to technology by the Informatics students. The data collected also shows that disregard of the discipline of their study, more than $50 \%$ of the respondents are spending 5 hours and above online every day and about $90 \%$ of them do used Social Media Technologies (SMTs) for academic purposes. Thus, academic instructors and higher education institutions should tap on this trend and opportunity to consider embracing social media technologies as tool for engaging student with the Institution, and academics, as well as for teaching and learning activities. The central outcome of this research will be the development of a design framework that will be used as a guide for Malaysian Higher Education Institutions and Informatics academics to engage students using SMTs in creating effective learning communities for Informatics Programs.

\section{REFERENCES}

1. Abdul Hamid N, Ishak M. S, Ismail S.A and Mohmad Yazam S.Y.N, 2013. Social Media and the New Academic Environment: Pedagogical Challenges - Chapter 12: Social Media Usage among University Students in Malaysia. Pp 244-255. IGI Global. DOI: 10.4018/978-1-4666-2851-9.ch012. Retrieved from: http://www.irmainternational.org/viewtitle/73316/

2. Al-Rahmi W.M, Othman M. S, and Musa N.A, (2014). The Improvement of Students' Academic Performance by Using Social Media through Collaborative Learning in Malaysian Higher Education. Asian Social Science; Vol. 10, No. 8 (pp 210-221)

3. Al-Rahmi W.M, Othman M. S (Undated). The Impact of Social Media use on Academic Performance among university students: A Pilot Study. Journal of Information Systems Research and Innovation. Retrieved from: http://seminar.utmspace.edu.my/jisri/download/G_FinalPublished/Pub12_SocialMediaAcademicPerformance.pdf

4. Anderson, P. (2007). What is Web 2.0?: Ideas, technologies and implications for education. JISC, 1(1). Bristol, UK.

5. Bartlett-Bragg (2006). Reflections on pedagogy: Reframing practice to foster informal learning with social media. Retrieved from: http://matchsz.inf.elte.hu/tt/docs/Anne20Bartlett-Bragg.pdf. (pp 2)

6. Bennett S., Maton, K and Kervin,L. (2008). The 'digital natives' debate: A critical review of the evidence, British Journal of Educational Technology, 39 (5): 775 - 786

7. Bennett S, Maton, K (2010). Beyond the 'digital natives' debate: Towards a more nuanced understanding of students' technology experiences. Journal of Computer Assisted Learning (2010), 26, 321 - 331. Blackwell Publishing Ltd.

8. Boitshwarelo B (2011). Proposing an Integrated Research Framework for Connectivism: Utilizing Theoretical Synergies. International Review of Research in Open and Distance Learning. Vol. 12.3. Retrieved from http://www.irrodl.org/index.php/irrodl/article/viewFile/881/1830\#

9. Brown, T.H. (2006). Beyond constructivism: Navigationism in the knowledge era. On the Horizon, 14(3), 108-120. Retrieved from http://www.emeraldinsight.com/journals.htm?articleid=1567661 
10. Cluett, L. \& Skene, J. (2007) A new(er) dimension to online learning communities: using web tools to engage students. Student Engagement: Teaching and Learning Forum, The University of Western Australia, January 2007. Retrieved from: https://otl.curtin.edu.au/professional_development/conferences/tlf/tlf2007/refereed/cluett.html

11. Corrin, L., Bennett, S., \& Lockyer, L. (2010). Digital natives: Everyday slife versus academic study. Paper presented at the Proceedings of the 7th International Conference on Networked Learning, Aalborg, Denmark. 643-650. Retrieved from http://ro.uow.edu.au/cgi/viewcontent.cgi?article=1214\&context=edupapers

12. Creswell J.H, 2003. Research Design - Qualitative, Quantitative, Mixed Methods Approaches, $2^{\text {nd }}$ Edition. SAGE Publications. $96-100$.

13. Dabbas N and Kitsantas A (2012). Personal Learning Environments, social media, and self-regulated learning: A natural formula for connecting formal and informal learning. Internet and Higher Education 15 (2012) 3-8. Elsevier

14. Davis, Deil-Amen, Rios-Aguilar, \& Gonzalez Canche (2012). Social Media in Higher Education - A Literature review and research directions. The Center for the Study of Higher Education at The University of Arizona AND $\begin{array}{llll}\text { Claremont } \quad \text { Graduate } & \text { University. } & \text { Retrieved }\end{array}$ http://www.academia.edu/1220569/Social_Media_in_Higher_Education_A_Literature_Review_and_Research_Direc tions

15. Eijkman, H. (2008). Web 2.0 as a non-foundational network-centric learning space. Campus-Wide Information Systems, 25(2), 93-104

16. Frand, J. (2000). The information-age mindset: changes in students and implications for higher education. EDUCAUSE Review, 35, September-October, 14-24.

17. Giesbrech, N. (2007). Connectivism: Teaching and learning. Retrieved from: http://design.test.olt.ubc.ca/Connectivism:_Teaching_and_Learning

18. Hamat A, Embi M. A, Abu Hasan H, (2012a). The use of Social Networking Sites Among Malaysian University Students. International Education Studies, Vol. 5, No. 3 (Page 56-66)

19. Hamat A, Embi M. A, Abu Hasan H, (2012b). Top-Performing Students' Use of Social Networking Sites. Research Journal of Applied Sciences, Engineering and Technology 5(2): (pp 361-369)

20. Hrastinkski S and Aghaee N.M (2011). How are campus students using social media to support their studies? An explorative interview study. Education and Information Technologies, Volume 17, No. 4. P 451-464.

21. Jo Bloggs (2005). Connectivism and Communities of Practice, Retrieved on $15^{\text {th }}$ April 2013 from http://westonedes.blogspot.com/2005/12/connectivism-and-communities-of.html

22. Joosten, T. (2012). Social media for educators: Strategies and best practices. Hoboken, NJ, USA: Jossey-Bass.

23. Kennedy, G., Krause, K., Churchward, A., Judd, T. \& Gray, K. (2006). First Year Students' Experiences with Technology: Are they really Digital Natives? Internal report, The University of Melbourne.

24. Kennedy, Judd, Dalgarno and Waycott (2010). Beyond natives and immigrants: exploring types of net generation students. Journal of Computer Assisted Learning (2010), 26, 332-343

25. Kvavik, R. B., Caruso, J. B., \& Morgan, G. (2004). ECAR Study Of Students And Information Technology 2004: Convenience, Connection, and Control. Boulder, CO: EDUCAUSE Center for Applied Research. Retrieved February 21, 2007, from http://www.educause.edu/ir/library/pdf/ers0405/rs/ers0405w.pdf

26. Levy, P. (1999). Collective Intelligence: Mankind's Emerging World in Cyberspace. Basic Books.

27. Lygouriatis C (2013), The Social Media Phenomenon. Christos Lygouriatis.com. Retrieved from: http://christoslygouriatis.com/the-social-media-phainomenon/

28. Nielsen M (2010), Collective Intelligence, by Pierre Levy, para 3, Retrieved from: http://michaelnielsen.org/blog/collective-intelligence-by-pierre-levy/

29. McLoughlin, C., \& Lee, M. J. W. (2010). Personalised and self regulated learning in the web 2.0 era: International exemplars of innovative pedagogy using social software. Australasian Journal of Educational Technology, 26(1), 2843.

30. Margaryan, A., Littlejohn, A. and Vojt, G. (2011) 'Are digital natives a myth or reality? University students' use of digital technologies,' Computers and Education, vol. 56, pp. 429-440. Retrieved from http://www.unil.ch/webdav/site/magellan/shared/Are_digital_natives_a_myth_or_reality_.pdf

31. Merchant, G. (2012). Mobile practices in everyday life: Popular digital technologies and schooling revisited. British Journal of Educational Technology, 43(5), 770-782.

32. MOHE Web Statistics, 2012. INDIKATOR Pengajian Tinggi Malaysia 2011-2012. Retrieved from http://www.mohe.gov.my/web_statistik/Indikator_PT-2011-2012.pdf. Accessed on $4^{\text {th }}$ Feb 2014. 
33. Abdul Hamid N, Ishak M. S, Ismail S.A and Mohmad Yazam S.Y.N (2013). "Social Media Usage among University Students in Malaysia. "Social Media and the New Academic Environment: Pedagogical Challenges”. IGI Global, page. 244-255.

34. Rubin, N. (2010). Creating a user-centric learning environment with Campus Pack personal learning spaces. : PLS Webinar, Learning Objects Community http://community.learningobjects.com/Users/Nancy.Rubin/Creating_a_UserCentric_Learning

35. Selwyn, N. (2010). Looking beyond learning: Notes towards the critical study of educational technology. Journal of Computer Assisted Learning, 26(1), 65-73.

36. Shittu, Madarsha and Tunku Ahmad (2011). Investigating students' attitude and intention to use Social software in higher institution of learning in Malaysia. Retrieved from: http://eli.elc.edu.sa/2011/sites/default/files/slides/

37. Siemens, G (2004). Connectivism: A Learning Theory for the Digital Age. Elearnspace. Retrieved from: http://www.ingedewaard.net/papers/connectivism/2005_siemens_ALearningTheoryForTheDigitalAge.pdf

38. Siemens, G. (2007). Digital natives and immigrants: a concept beyond its best before date. Retrieved from http://connectivism.ca/blog/2007/10/digital_natives_and_immigrants.html.

39. Tess, P.A (2013), The role of social media in higher education classes (real and virtual) - A literature review. Computers in Human Behavior 29 (2013) A60-A68. SciVerse ScienceDirect.

40. Tapscott, D. (2008) Grown up digital: How the Net generation is changing your world. New York: McGraw-Hill (p 11)

41. Wenger E (1998), Communities of Practice: Learning, Meaning, and Identity, Cambridge: Cambridge University Press, pp. 318, ISBN 978-0-521-66363-2 